\title{
On a peculiar case in the refraction of organic compounds
}

\section{R. Nasini \& T. Costa}

To cite this article: R. Nasini \& T. Costa (1891) On a peculiar case in the refraction of organic compounds, Philosophical Magazine Series 5, 31:192, 448-448, DOI: 10.1080/14786449108620142

To link to this article: http://dx.doi.org/10.1080/14786449108620142

曲 Published online: 08 May 2009.

Submit your article to this journal $[\pi$

Џ Article views: 2

Q View related articles $\asymp$ 
in the oxygen tested. Even when the gas was passed for some time through a solution of iodide of potassium and starch no blue colour was perceived. The oxygen used for the experiment remained for a week in the iron reservoir into which it was pumped in contact with solid potassic hydrate, by which it was completely freed from $\mathrm{CO}_{2}$, from chlorine, and from aqueous vapour.

From these experiments there can be no doubt that oxygen in the liquid condition, and in layers of about 30 millim., has a decidedly bright blue colour. This colour of oxygen agrees very well with its absorption-spectrum. It was surprising that a colourless liquid, such as oxygen was supposed to be, had such a pronounced absorption-spectrum, in which the absorptions predominate in orange, in yellow, and in red. But this apparent contradiction has been removed by the above experiments of the author.

One word in conciusion as to the colour of the sky. There are, as it is known, so many hypotheses which attempt to explain this that the author scarcely dares to propound another. But in his opinion this phenomenon would be most readily explained by ascribing the blue colour of the sky to this constituent of the atmosphere, which has a blue colour, at any rate in the liquid state.Wiedemanu's Annalen, xlii. p. 663.

\section{ON A PECULIAR CASE IN THE REERACTION OF ORGANIC COMPOUNDS. BY R. NASINI AND T. COSTA.}

The authors bave found a compound formed by the simple union of two others, which, instead of having a molecular refraction double the sum of those of the components, has a far greater one. This compound is the iodide of triethylsulphine, the components being iodide and sulphide of etbyl. The constants are for the compound $V$, and for the mixture of both, $G, 5 \cdot 085 \mathrm{gr}$. of each dissolved in 100 cubic centim.

$$
\begin{aligned}
& d_{4}^{20} . \quad{ }^{\mu} \mathrm{H}_{\alpha} . \quad \frac{{ }^{\mu} \mathrm{H}_{\alpha}^{2-1}}{d} \cdot \frac{{ }^{\mu} \mathrm{H}_{\alpha}^{2+2}}{\left(\mathrm{H}_{\alpha}^{2-1}\right) d} . \\
& \begin{array}{llllll}
\text { V } \ldots . .8 & 0.81761 & 1.36857 & 0.45079 & 0.27568
\end{array} \\
& \text { G } \ldots . .0 .81076 \quad 1.36414 \quad 0.44926 \quad 0.27509
\end{aligned}
$$

The sulphur has therefore a far greater atomic refraction in the compound than in the mixture. It might be supposed that this arises from the fact that the sulphur in the compound is $S^{\text {iv }}$ and in the sulphide $\mathrm{S}^{\prime \prime}$; but this would not agree with the deportment of oxygen compounds in sulphur.-Rend. $R$. Acc. dei Linc. vi. pp. 259-263 (1890); Beiblätter der Physik, No. 2, 1891. 